\author{
Jarosław Sokołowski*
}

\title{
WARTOŚĆ KAPITAŁU INTELEKTUALNEGO PRZEDSIEBIORSTWA JAKO PODSTAWA OCENY I WYNAGRADZANIA MENEDŻERÓW
}

\section{WSTĘP}

Jeden z paradygmatów współczesnego przedsiębiorstwa jako organizacji uczącej się wskazuje na dwa istotne fakty. Po pierwsze na znaczenie kapitału intelektualnego jako czynnika rozwoju przedsiębiorstwa, zaś po drugie na znaczenie zasobów ludzkich przedsiębiorstwa jako istotnego nośnika wiedzy i kapitału intelektualnego.

Z punktu widzenia zarządzania współczesnym przedsiębiorstwem kapitał intelektualny stanowi zarazem czynnik jak i komponent wartości przedsiębiorstwa, a w szczególności ekonomicznej wartości dodanej jako nadwyżki jego wartości rynkowej nad wartością wniesionych do przedsiębiorstwa kapitałów finansowych. Przytaczane wielokrotnie w literaturze badania wskazują (niezależnie od konkretnie przytaczanych liczb), że znacząca część wartości współczesnych przedsiębiorstw wynika $\mathrm{z}$ istnienia aktywów niematerialnych, aktywów „ukrytych” stanowiących główną substancję kapitału intelektualnego. Powyższe w całej rozciągłości dotyczy przedsiębiorstw działających w sektorach nowych technologii, informatyki i telekomunikacji, mediów itp.

Znaczący, jeśli nie podstawowy, wpływ na tworzenie i efektywne wykorzystanie kapitału intelektualnego przedsiębiorstwa ma kadra kierownicza i specjaliści zatrudnieni w przedsiębiorstwie. To oni tworzą nową wiedzę, pozyskuja ją z otoczenia i wykorzystują dla budowania wartości przedsiębiorstwa i jego przewagi konkurencyjnej na rynku. Szczególną odpowiedzialność w tym wzgledzie ponosi, naczelna kadra kierownicza przedsiębiorstw. Można, jak się wydaje przyjąć, iż swoista ,wydolność” przedsiębiorstwa w zakresie budowania i wyko-

\footnotetext{
${ }^{*}$ Dr, Społeczna Akademia Nauk w Łodzi.
} 
rzystywania kapitału intelektualnego powinna być istotnym elementem oceny naczelnego kierownictwa przedsiębiorstwa oraz kształtowania wysokości jego wynagrodzenia.

Celem niniejszego artykułu jest sformułowanie wstępnych propozycji dotyczących oceny i wynagrodzeń naczelnego kierownictwa przedsiębiorstw, w szczególności działających w formie spółek kapitałowych uczestniczących w rynku kapitałowym.

\section{KAPITAŁ INTELEKTUALNY JAKO KOMPONENT WARTOŚCI WSPÓŁCZESNEGO PRZEDSIĘBIORSTWA}

Pojecie „kapitał intelektualny” pojawiło się w odniesieniu do organizacji już w latach 60. XX w. Wtedy już zwrócono uwagę na znaczenie niewymiernych czynników wzrostu i rozwoju przedsiębiorstwa, związanych z szeroko rozumianą wiedzą, doświadczeniem i pozostałymi niematerialnymi czynnikami rozwoju przedsiębiorstw. Zaczęto wtedy zauważać, że wartość przedsiębiorstw rejestrowana na rynkach, znacząco niekiedy odbiega od ich wartości księgowej, a na ich pozycję konkurencyjną na rynkach dóbr i usług mają wpływ niewymierne czynniki znajdujące się poza dotychczas analizowanymi czynnikami kapitałowymi. Zaczęto zgodnie przypisywać to zjawisko istnieniu różnorodnych czynników działalności przedsiębiorstw związanych $\mathrm{z}$ ich kapitałem ludzkim, zasobami wiedzy, informacjami o specyficznym znaczeniu, tajnikami technologii, procesów, tajemnic firmy i innymi tego rodzaju czynnikami, zwanymi też często ukrytymi aktywami organizacji.

Można więc stwierdzić, że wiedza zgromadzona w organizacji, wiedza zespołów i pojedynczych pracowników oraz inne aktywa niematerialne, stanowią podstawę wyodrębnienia kapitału intelektualnego każdej organizacji, w tym oczywiście przedsiębiorstw ${ }^{1}$.

Większość autorów wskazuje na to, że składniki kapitału intelektualnego posiadają zdolność do kreowania wartości, w rożnym rozumieniu tego pojęcia, to jest wartości rynkowej przedsiębiorstwa, wartości dla akcjonariuszy, czy wartości dla klientów. Koncepcja ta wpisuje się bardzo mocno we współczesne koncepcje wzrostu wartości jako celu współczesnego przedsiębiorstwa, zarządzania wartością przedsiębiorstwa, czy tak zwanej ekonomicznej wartości dodanej (EVA).

Wydaje się, że najbardziej trafnymi i przejrzystymi koncepcjami definiującymi istotę i zakres pojęcia kapitału intelektualnego, są koncepcje M. Bratnickiego oraz L. Edvinssona i M. S. Malone. Prezentują je odpowiednio rys. 1 i 2.

${ }^{1}$ A. P. Wi atrak, Zarzqdzanie wiedzq $i$ kapitatem intelektualnym $w$ organizacji - istota i podstawowe zależności, „Problemy Zarządzania” 2007, nr 4, s. 12. 


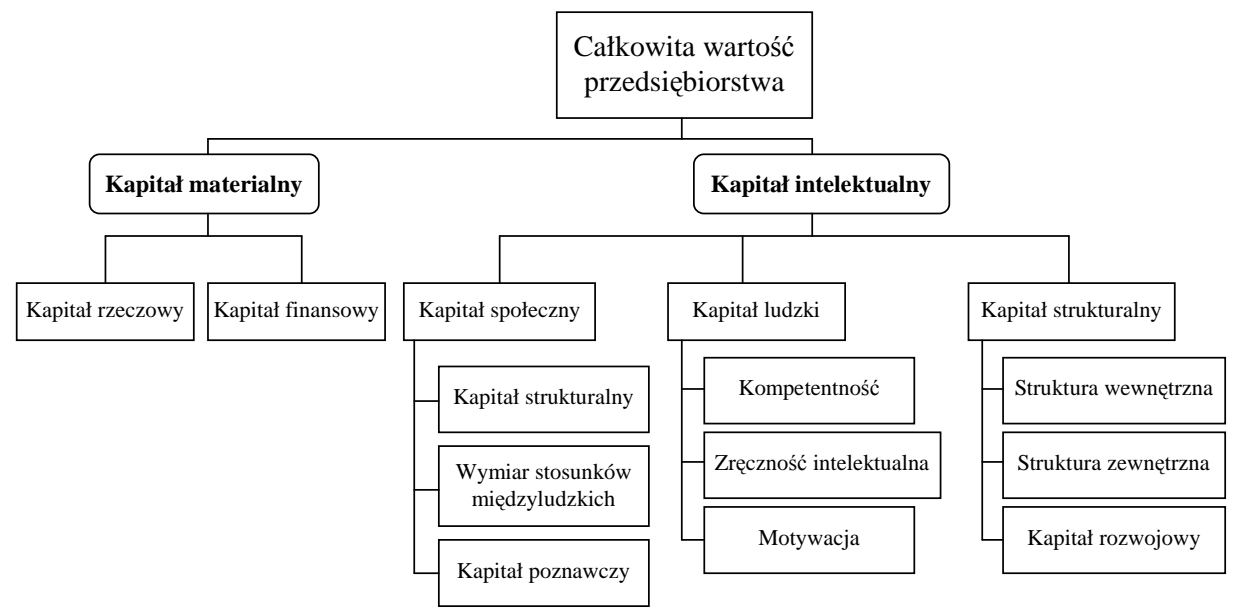

Rys. 1. Drzewo wartości przedsiębiorstwa

Źródło: M. Bratnicki, J. Strużyna, W. Dyduch, Kapitat intelektualny - odwieczne problemy a nowe propozycje metodologiczne, [w:] Kapitat intelektualny, dylematy $i$ wyzwania, WSB-NLU, Nowy Sącz 2001.

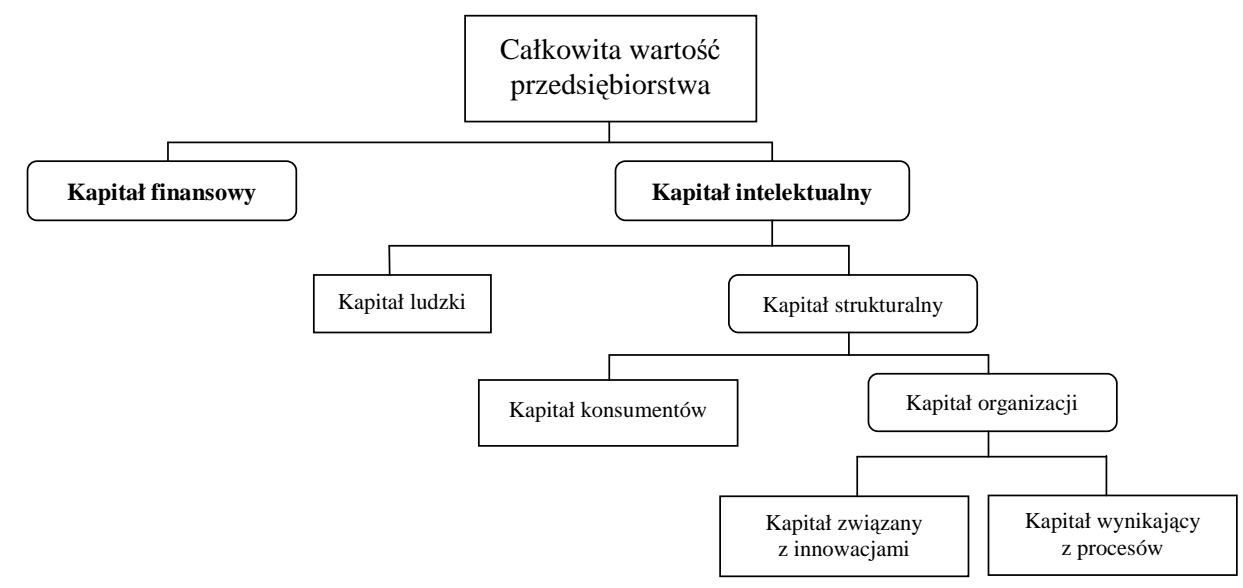

Rys. 2. Kapitał intelektualny według Leifa Edvinssona

Źródło: D. Dobija, Możliwości pomiaru kapitału intelektualnego organizacji i jego prezentacji w sprawozdaniach finansowych, Zeszyty Naukowe AE w Krakowie, Z. 553, Kraków 2000 . 
Obie przedstawione koncepcje za punkt wyjścia dla określenia i ewentualnego pomiaru kapitału intelektualnego przedsiębiorstwa przyjmują całkowitą wartość rynkową przedsiębiorstwa, którą w przypadku przedsiębiorstw spółek notowanych na publicznym rynku akcji (giełdzie) rozumiemy jako tak zwaną giełdową kapitalizację spółki, czyli iloczyn akcji spółki i ich aktualnego kursu, bądź na przykład średniego kursu wyliczonego dla jakiegoś okresu. Na wartość rynkową przedsiębiorstwa w tych koncepcjach składa się zatem księgowo określona wartość ich kapitałów materialnych (rzeczowych i finansowych) oraz wartość ich aktywów niematerialnych będących właśnie kapitałem intelektualnym. M. Bratnicki nazywa swą koncepcję drzewem wartości przedsiębiorstwa².

W myśl powyższych koncepcji, głównymi składowymi kapitału intelektualnego przedsiębiorstwa są:

- kapitał ludzki, to jest szeroko rozumiana wiedza i kompetencje personelu i kadry kierowniczej przedsiębiorstw,

- kapitał strukturalny (organizacyjny) tkwiący w strukturach, zarządzaniu, procesach, wiedzy organizacyjnej, innowacyjności i wewnętrznych relacjach w firmie,

- kapitał relacyjny, wynikający z wiedzy zdobywanej przez przedsiębiorstwo w wyniku budowania relacji z otoczeniem.

Niezmiernie ważnym komponentem kapitału intelektualnego przedsiębiorstwa jest także tak zwany kapitał społeczny oparty na wewnętrznych i zewnętrznych relacjach, komunikacji, zaufaniu, wspólnych wartościach. Kapitał ten tkwi zarówno w kapitale ludzkim, jak też w kapitale organizacyjnym i relacyjnym ${ }^{3}$.

Przytaczane w literaturze wyniki badań wskazują, iż w praktyce funkcjonowania przedsiębiorstw elementami składowymi kapitału intelektualnego są przeważnie ${ }^{4}$ :

- zaangażowani i efektywni pracownicy,

- wiedza aktualizowana i utrwalana,

- pełna dostępna wiedza o klientach,

- trwałe personalne związki z klientami,

- efektywna komunikacja,

- innowacyjność,

- wysoka jakość produktów,

- rozwojowy portfel produktowy.

Warto zauważyć, że wszystkie wymienione składowe kapitału intelektualnego przedsiębiorstwa są zarówno podstawą rozwoju i budowania wartości przedsiębiorstwa, jak również efektem tego rozwoju. Jest to więc typowe zjawisko sprzężenia zwrotnego pomiędzy rozwojem przedsiębiorstwa, a tworzeniem

\footnotetext{
${ }^{2}$ M. B ratnicki, Pomiar kapitału intelektualnego, ,Ekonomika i Organizacja Przedsiębiorstwa" 2000, nr 11.

${ }^{3}$ A. P. Wi atrak, op. cit., s. 13.

${ }^{4}$ A. S opińska, P. W a chowiak, Jak mierzyć kapitat intelektualny $w$ przedsiębiorstwie, „E-Mentor” 2004, nr 2.
} 
kapitału intelektualnego i tworzeniem kapitału intelektualnego, a rozwojem przedsiębiorstwa. To, co należy uznać, jak się wydaje, za niewątpliwe, to fakt swoistego przekraczania przez kapitał intelektualny tradycyjnie rozumianych granic przedsiębiorstwa jako organizacji. Jest to szczególnie oczywiste w przypadku przedsiębiorstw globalnych, sieciowych, bądź wirtualnych, coraz silniej oddziałujących na współczesną gospodarkę.

Określanie wartości kapitału intelektualnego przedsiębiorstwa, zgodnie z przyjętymi koncepcjami jego definiowania, może być dokonywane poprzez wyliczenie go jako 5 :

a) różnicy wartości rynkowej i wartości księgowej przedsiębiorstwa,

b) sumy wartości składników aktywów niematerialnych składających się na kapitał intelektualny oraz wartości kapitału ludzkiego.

Jeśli idzie o metodę rynkowej wyceny kapitału intelektualnego przedsiębiorstwa, to najczęściej stosowane są następujące formuły obliczania wartości kapitału intelektualnego.

Pierwszą jest formuła Edvinssona i Malone, wyrażona w następujący sposób:

$$
K I=M V-B V
$$

gdzie:

$K I \quad$ - kapitał intelektualny,

$M V$ - wartość rynkowa przedsiębiorstwa,

$B V$ - wartość księgowa przedsiębiorstwa.

Przyjętymi kanonami wyceny wartości $K I$ są następujące:

- wartość $M V$ to tak zwana kapitalizacja giełdowa spółki, czyli iloczyn liczby akcji spółki i tak czy inaczej przyjętego jej kursu giełdowego,

- wartość $B V$ określana jako suma aktywów pomniejszona o zobowiązania, czyli wartość kapitałów własnych przedsiębiorstwa.

Warto w tym miejscu zasygnalizować, iż przyjmowanie wielkości $B V$ do szacowania kapitału intelektualnego może budzić pewne wątpliwości. Z ekonomicznego punktu widzenia wartość $B V$ winna być ujmowana jako wartość bilansowa spółki, a nie jako wartość aktywów netto. Warto także zwrócić uwagę na niestabilny charakter kapitalizacji rynkowej, jako podstawy szacowania wartości kapitału intelektualnego.

Kolejną formułą obliczania wartości (a właściwie wskaźnika) kapitału intelektualnego przedsiębiorstwa jest formuła Q-Tobina zawarta we wskaźniku:

$$
Q=M V / R V
$$

\footnotetext{
${ }^{5} \mathrm{~J} . \mathrm{Fij}$ ałk ow ska, Finansowe $i$ nie finansowe metody pomiaru oraz prezentacji $w$ sprawozdaniach kapitału intelektualnego, rozprawa doktorska, SWSPiZ, Łódź 2009, s. 107.
} 
gdzie:

$Q \quad$ - wskaźnik kapitału intelektualnego,

$M V$ - wartość rynkowa przedsiębiorstwa,

$R V$ - wartość odtworzeniowa aktywów przedsiębiorstwa.

Nie podważając wartości poznawczej i analitycznej tego wskaźnika, należy stwierdzić, że wycena wartości odtworzeniowej aktywów nastręczać może poważnych problemów metodologicznych i informacyjnych i z natury rzeczy być bardzo pracochłonną i kosztowną.

Kolejną formułą w tej grupie jest metoda VAIC (value addend intellectual coefficient). Jest to wielostopniowa procedura wyceny składników kapitału intelektualnego, efektywności ich wykorzystania w przedsiębiorstwie oraz łącznej efektywności zaangażowanych w przedsiębiorstwie kapitałów. Nie wchodząc w całość zawartej w tej metodzie analizy, przedstawimy jedynie jej pierwszy krok, który w zasadzie może służyć jako formuła wyceny kapitału intelektualnego przedsiębiorstw. Za punkt wyjścia bierzemy wartość rynkową przychodów przedsiębiorstwa, w której przecież także zawiera się wycena rynkowa kapitału intelektualnego poprzez wycenę rynkową produktów przedsiębiorstwa. Postać formuły jest następująca:

$$
V A=O U T-I N
$$

gdzie:

$V A$ - wartość dodana,

OUT - przychód ze sprzedaży,

IN - wydatki materialne związane ze sprzedażą.

Trudno zaprzeczyć, że wartość dodana wytworzona w przedsiębiorstwie i zrealizowana na rynku zawiera w sobie kapitał intelektualny przedsiębiorstwa. Należy jednakże zauważyć, że w pojemności tak skonstruowanego miernika wartości dodanej znajduje się amortyzacja, a także całość wydatków na personel co może budzić wątpliwości.

Za proponowanym wyżej sposobem ujmowania wartości księgowej spółki przemawiają następujące argumenty ${ }^{6}$ :

- w istocie rzeczy wartość rynkowa przedsiębiorstwa obejmuje w swej pojemności kapitały obce, szczególnie, gdy jest wyższa od sumy bilansowej,

- rynek wycenia przedsiębiorstwa nie na podstawie efektywności zastosowania kapitałów własnych, ale raczej kapitałów łącznych,

${ }^{6}$ J. Duraj (red.), Instrumenty $i$ sposoby zarzqdzania kapitatem przedsiębiorstwa, „Acta Universitatis Lodziensis" 2012, Folia Oeconomica 267, Wydawnictwo Uniwersytetu Łódzkiego, Łódź, s. 60. 
- aktywa intelektualne w istocie rzeczy mogą powstawać na finansowej bazie zarówno kapitałów własnych jak również kapitałów obcych,

- biorąc pod uwagę stosunkowo duży wskaźnik zadłużenia wielu korporacji światowych, przekraczający niekiedy znacznie 50\% sumy aktywów, w wielu przypadkach może dochodzić do przeszacowania wartości kapitału intelektualnego.

W odniesieniu do ostatniego z wymienionych argumentów należy wyraźnie stwierdzić, że w przypadku przedsiębiorstw o wysokim wskaźniku finansowania aktywów zobowiązaniami, wartość kapitału intelektualnego może w swoisty sposób podlegać ,,pompowaniu” poprzez przyrost wartości wynikający z przyrostu zobowiązań. Sytuacja taka na pewno powoduje istotne zakłócenia w obiektywnym szacowaniu kapitału intelektualnego.

\section{ROLA MENEDŻERÓW W TWORZENIU KAPITAŁU INTELEKTUALNEGO PRZEDSIĘBIORSTWA}

Kapitał intelektualny przedsiębiorstwa to kategoria tyleż istotna dla rozwoju i konkurencyjności przedsiębiorstwa, co ulotna. To ostatnie nie przekreśla jednakże faktu, że ze względu na wiele okoliczności zarówno wewnętrznych, jak i zewnętrznych w zarządzaniu przedsiębiorstwem, należy dążyć do zobiektywizowanego pomiaru wartości kapitału intelektualnego przedsiębiorstw. Metody pomiaru kapitału intelektualnego, a także szacowania jego wpływu na wartość i rozwój przedsiębiorstwa powinny uwzględniać różnorodne realia ekonomiczne, finansowe i księgowe, a także mieć istotną wartość poznawczą i analityczną.

Pojawia się zatem pytanie, na ile wartość kapitału intelektualnego przedsiębiorstwa może stanowić po pierwsze podstawę oceny kadry menedżerskiej przedsiębiorstwa, a po drugie, na ile winna być ona podstawą kształtowania wynagrodzeń tejże kadry. Pragniemy tu zaznaczyć, że przedmiotem naszego zainteresowania jest w szczególności naczelna kadra kierownicza dużych przedsiębiorstw działających w formie organizacyjno-prawnej spółki akcyjnej notowanej na publicznym rynku kapitałowym, czyli po prostu na giełdzie papierów wartościowych. Ponadto mamy tu w zasadzie na uwadze sytuację polegającą na rozdzieleniu własności od zarządzania, to znaczy sytuację zarządzania przedsiębiorstwami (spółkami) przez wynajętych w tym celu menedżerów.

Otóż wydaje się, że niezależnie od tego, czy jako formułę określania wartości kapitału intelektualnego przyjmiemy formułę liczenia tej wartości jako różnicy wartości rynkowej spółki i jej wartości księgowej, czy będziemy się opierać na wciąż niejednoznacznej i budzącej szereg wattpliwości formule $V A I C^{7}$, to

\footnotetext{
${ }^{7}$ Por. G. Urbane k, L. B ohd anowic z, Krytyczna analiza wspótczynnika intelektualnej wartości dodanej, „Przegląd Organizacji” 2012, nr 11.
} 
w każdym przypadku występują co najmniej dwie okoliczności, określające rolę menedżerów w tworzeniu kapitału intelektualnego.

Po pierwsze, sami menedżerowie, ze swą wiedzą, umiejętnościami, doświadczeniem i wszelkimi innymi kompetencjami niezbędnymi w danym biznesie, są istotną, a niekiedy wiodącą składową kapitału intelektualnego przedsiębiorstwa. Rynek kapitałowy wycenia bowiem funkcjonujące na nim spółki między innymi przez pryzmat zarządzających nimi menedżerów. To wartości wnoszone przez menedżerów do spółki są ważną składową wartości dodanej kreowanej w tych spółkach. Można więc tę rolę menedżerów w kreowaniu kapitału intelektualnego nazwać rolą ,samą w sobie”.

Po drugie, menedżerowie pełnią zewnętrzną, „zarządczą" rolę w stosunku do kreowanego w przedsiębiorstwach kapitału intelektualnego. Podejmując określone decyzje w procesie zarządzania przedsiębiorstwami, wywierają istotny wpływ na kształtowanie się podstawowych wielkości ekonomicznych, takich jak wartość bilansowa przedsiębiorstwa, struktura finansowania aktywów, bieżąca wartość giełdowa firmy (choć w tym przypadku wpływ zarządu spółki jest zawsze mniej lub bardziej ograniczony), przychody ze sprzedaży, koszty działalności, wartość dodana, marże, zyski itd. Wszystkie te wartości mają, jak wiadomo, bezpośrednie znaczenie dla wyceny kapitału intelektualnego przedsiębiorstwa i w znacznym stopniu są uwarunkowane racjonalnymi i trafnymi decyzjami menedżerów. Ponadto menedżerowie poprzez swe decyzje, działania, kształtowanie klimatu i kultury organizacji przyczyniają się pozytywnie, albo negatywnie do budowania poszczególnych składników kapitału intelektualnego we wszystkich jego wymiarach, to znaczy kapitału ludzkiego, kapitału organizacyjnego i kapitału relacyjnego. Tak więc i w tym rozumieniu, rola i wpływ menedżerów na kształtowanie kapitału intelektualnego przedsiębiorstwa jest nie do przecenienia.

\section{PROPOZYCJE KSZTAETOWANIA WYNAGRODZEŃ MENEDŻERÓW W POWIĄZANIU Z KAPITALEM INTELEKTUALNYM PRZEDSIĘBIORSTWA}

Zachodzi zatem ważne pytanie, czy wartość kapitału intelektualnego przedsiębiorstwa jako komponentu jago całkowitej wartości, może być podstawą oceny naczelnej kadry kierowniczej przedsiębiorstw oraz kształtowania wynagrodzeń tej kadry. Wydaje się, że jest to propozycja dość atrakcyjna i na pewno warta rozważenia. Mieści się ona w ogólnej strategii wzbogacania narzędzi mo- 
tywowania kadry kierowniczej i wszystkich pracowników przedsiębiorstw, która powinna przyczyniać się do ${ }^{8}$ :

- sprostania współczesnej konkurencji w globalizującej się gospodarce,

- tworzenia i wykorzystania wiedzy jako głównego czynnika konkurencyjności,

- budowy kapitału intelektualnego przedsiębiorstwa.

Wyżej wskazaliśmy na oczywistą i ogromną rolę jaką mają do spełnienia w powyższym menedżerowie. W tym miejscu należy skonkretyzować, iż używając terminu „menedżerowie” mamy na myśli zarządy spółek kapitałowych oraz ewentualnie najbliższe ich zaplecze występujące w dużych spółkach w postaci dyrektorów sprawujących zarząd operacyjny w przedsiębiorstwach tych spółek. Można bowiem, jak się wydaje przyjąć, że w odniesieniu do tych dwóch grup menedżerów (o ile w danej spółce obie te grupy występuja), mogą funkcjonować podobne zasady oceny i wynagradzania, ze względu na podobieństwo realizowanych celów i istniejący układ motywacji.

Współcześnie podchodzimy szeroko do określenia zakresu pojęcia wynagrodzeń. Dotyczy to także kadry menedżerskiej. W przypadku tej grupy przyjmuje się na ogół, że na wynagrodzenia składają się następujące elementy: wynagrodzenia finansowe, świadczenia rzeczowe i usługowe, wartości niematerialne związane z samorealizacją i prestiżem zawodowym i osobistym ${ }^{9}$. Jak dotychczas głównym przedmiotem badań są oczywiście wynagrodzenia finansowe oraz w pewnym zakresie świadczenia rzeczowe i usługowe.

Jeśli idzie o wynagrodzenia finansowe menedżerów spółek i przedsiębiorstw, to można zauważyć, że na ogół zawierają one część stałą i część ruchomą, co z resztą dotyczy większości pozostałego personelu. Specyficzną składową wynagrodzeń menedżerów szczytowych szczebli organizacji gospodarczych jest występowanie tak zwanych wynagrodzeń odroczonych, które w przeważającej mierze mają charakter ruchomy. Są to inaczej mówiąc tak zwane bodźce długoterminowe, mające na celu długookresowe motywowanie menedżerów $(L T I)^{10}$.

Wynagrodzenie stałe menedżerów może w pewien sposób nawiązywać do wartości kapitału intelektualnego przedsiębiorstwa poprzez to, że wysokość stałej pensji powinna odzwierciedlać stopień merytorycznej oraz biznesowej złożoności firmy, zaś po drugie także indywidualne kompetencje danego menedżera. W ten sposób wyraża się niejako jego osobisty wkład w wartość kapitału intelektualnego i wymagania kompetencyjne związane z kierowaniem przedsiębiorstwem o wysokim udziale kapitału intelektualnego w jego funkcjonowaniu

${ }^{8}$ J. S o k oło w s ki, Strategia wynagrodzeń a budowa kapitatu intelektualnego przedsiębiorstwa, [w:] E. Urbanow ska-S ojkin (red.), Wybory strategiczne w przedsiębiorstwach, Wydawnictwo Uniwersytetu Ekonomicznego w Poznaniu, Poznań 2011, s. 233.

${ }^{9}$ A. P o c z t o w s k i, Zarzqdzania zasobami ludzkimi, PWE, Warszawa 2007, s. 214.

${ }^{10}$ Por. P. U rban e k, Nadzór korporacyjny a wynagrodzenia menedżerów, Wydawnictwo Uniwersytetu Łódzkiego, Łódź 2005, s. 125-140. 
i rozwoju. Mechanizm ten ma jednak charakter raczej statyczny i może zawierać zbyt słabe bodźce do dalszego pomnażania kapitału intelektualnego przedsiębiorstwa.

Wynagrodzenia zmienne krótkookresowe są, jak wiadomo, nakierowane na pobudzanie menedżerów do skutecznego kreowania bieżącej efektywności ekonomicznej, w szczególności rentowności działalności przedsiębiorstwa w kolejnych latach. Mają temu służyć roczne premie powiązane zawsze pośrednio lub bezpośrednio z rentownością działalności przedsiębiorstwa. Formuła premiowania rocznego może się różnić w zależności od tego czy przyjmiemy model zadaniowy, model parametryczny, czy też model udziałowy premiowania ${ }^{11}$. W każdym z tych modeli w mniejszym bądź większym stopniu występuje rentowność bieżącej działalności przedsiębiorstwa jako kryterium oceny i wynagradzania menedżerów przedsiębiorstw. Nie można w sposób bezwzględny przekreślać znaczenia bieżącej rentowności przedsiębiorstwa dla kształtowania jego wartości, w tym także wartości kapitału intelektualnego. Nie mniej trzeba zauważyć, że wartość przedsiębiorstwa i kapitał intelektualny są kategoriami długookresowymi, zaś bieżąca rentowność jest jednak bardziej kategorią krótkookresową, a dążenie do osiągnięcia krótkookresowej efektywności ekonomicznej przedsiębiorstwa może stać w sprzeczności z jego długookresową konkurencyjnością i budowaniem kapitału intelektualnego oraz długookresowej wartości dla akcjonariuszy.

Z powyższych rozważań wynika, że możliwości motywowania menedżerów do długookresowego budowania wartości przedsiębiorstwa i kapitału intelektualnego należy poszukiwać w stosowaniu bodźców długookresowych (LTI). Wydaje się, że przede wszystkim w konstrukcji tych bodźców można zawrzeć spójny mechanizm motywacyjny, skłaniający menedżerów do wysiłków na omawianym tu polu. Oczywiście nie można wykluczyć wprowadzenia do mechanizmu premiowania rocznego wynagrodzenia za na przykład przyrost wartości spółki w okresie objętym premiowaniem. Jednakże w przypadku konsekwentnego utrzymywania premii od wyniku finansowego, wprowadzenie premii powiązanej z przyrostem wartości mogłoby nieco komplikować system i tworzyć bodźce konkurencyjne w krótkich okresach czasowych.

Najbardziej typowymi bodźcami długookresowymi, stosowanymi wobec kadry menedżerskiej przedsiębiorstw są:

- programy ubezpieczeń na życie z funduszami inwestycyjnymi oraz programy emerytalne,

- odprawy kończące zatrudnienie w danej firmie,

- programy udziału we własności, nazywane często opcjami menedżerskimi.

${ }^{11}$ J. S o k oło w s ki, R. Jó ź wi c ki, Wynagrodzenia naczelnego kierownictwa a efektywność $i$ wartość spótek kapitałowych, [w:] J. D u raj, Przedsiębiorstwo na rynku kapitałowym, Wydawnictwo Uniwersytetu Łódzkiego, Łódź 2010, s. 278. 
Pierwsza z wyżej wymienionych form ma raczej charakter zabezpieczający, i stanowi element wynegocjowanego przez menedżera pakietu wynagrodzeń, będąc albo świadczeniem zindywidualizowanym, albo może obejmować całe kierownictwo firmy, szczególnie w przypadku zakładowych programów emerytalnych. Pełniąc niewątpliwie ważne funkcje zarówno z punktu widzenia firmy, jak i poszczególnych menedżerów, forma ta nie wiąże się w żaden sposób $\mathrm{z}$ budowaniem kapitału intelektualnego.

Odprawy kończące zatrudnienie w firmie mogą mieć natomiast dwojakiego rodzaju charakter. Mogą być to odprawy o charakterze świadczeniowym, ale także mogą mieć one charakter motywacyjny. W przypadku pierwszym wysokość odprawy jest $\mathrm{z}$ góry określona $\mathrm{w}$ umowie o pracę, bądź jakiejś innej formie kontraktu menedżera $\mathrm{z}$ firmą. Wysokość odprawy jest wtedy określana albo kwotowo, albo jako krotność ostatnio pobieranego wynagrodzenia. Odprawa taka częstokroć wiąże się z zawartym w kontrakcie zakazem konkurencji $\mathrm{w}$ określonym czasie, pełniąc $\mathrm{w}$ tym przypadku funkcję odszkodowania za utracone dochody z pracy.

Odprawa może jednak mieć charakter motywacyjny, w przypadku gdy jest powiązana z realizacją przez menedżerów długookresowego celu akcjonariuszy. Odprawa taka przybiera na ogół formę tak zwanej premii za sukces, przy czym za miarę sukcesu przyjmowana jest na ogół zmiana wartości spółki w okresie zarządzania nią przez danego menedżera lub grupę menedżerów. W przypadku takim odprawa jest ustalana w oparciu o procentowy wskaźnik udziału menedżerów w przyroście wartości spółki. Wydaje się, że dla silniejszego powiązania tak skonstruowanej odprawy z tworzeniem kapitału intelektualnego, tak określana odprawa winna być wiązana z tą częścią przyrostu wartości spółki, która jest właśnie przyrostem wartości kapitału intelektualnego. Z punktu widzenia motywacji do budowania kapitału intelektualnego firmy w dłuższym horyzoncie czasowym, jest to, jak się wydaje, mechanizm o potencjalnie właściwym oddziaływaniu.

Trzeci rodzaj wynagrodzeń odroczonych, to różne formy udziału we własności, mające bardziej bezpośredni lub pośredni charakter. Forma bezpośrednia to wynagradzanie menedżerów akcjami firmy, na ogół bez prawa zbywania w określonym czasie. W naturalny sposób wiąże to interes menedżerów z interesem akcjonariuszy, a dążenie menedżerów do podnoszenia wartości firmy przyczynia się do tworzenia kapitału intelektualnego. Formą bardziej pośrednią są przydzielane menedżerom opcje na akcje firmy.

Menedżerowie chcąc osiagnąć w przyszłości wyższą wartość posiadanych aktywów, muszą w pełni wykorzystywać wszystkie czynniki wzrostu tej wartości, w tym oczywiście także czynniki niematerialne. W tej formie wynagradzania długookresowego zawarty jest niemal samoistnie mechanizm oceny i wynagradzania menedżerów przez pryzmat kapitału intelektualnego firmy. Pominęliśmy tu oczywiście cały szereg kwestii natury techniczno-finansowej związanych 
z programami opcji menedżerskich, jak również możliwych patologii, które ten system może wywołać, a które ujawniły się szczególnie mocno w czasie kryzysu finansowego poprzednich lat, będąc być może jedną z jego przyczyn. Można, jak się wydaje, zaryzykować stwierdzenie, że ta negatywna strona omawianego mechanizmu wynika nie tylko z jego natury, ale także ze słabości nadzoru korporacyjnego w wielkich spółkach, może w szczególności w jednopoziomowym modelu anglosaskim.

\section{PODSUMOWANIE}

Wiązanie oceny i wynagrodzeń menedżerów spółek z wartością tworzonego w nich kapitału intelektualnego jest niewątpliwie słusznym i pożytecznym kierunkiem w zarządzaniu współczesnymi organizacjami gospodarczymi. Menedżerowie tych organizacji winni być bowiem oceniani a następnie wynagradzani w oparciu o to, w jakim stopniu kierowane przez nich organizacje tworzą nową wartość, wynikającą z tworzenia i wykorzystania kapitału intelektualnego. Trzeba podkreślić, że wszystkie elementy omawianego w niniejszym artykule mechanizmu są wciąż niedopracowane i wymagają dalszych dociekań oraz gromadzenia i analizowania doświadczeń praktycznych. Dotyczy to zarówno samej kwestii pomiaru kapitału intelektualnego, uwolnienia tego pomiaru na przykład od czynników koniunkturalnych, jak też określenia właściwych priorytetów polityki wynagrodzeń, tak by sprzyjała tworzeniu omawianych w artykule mechanizmów motywacyjnych. Pomimo całego szeregu problemów interpretacyjnych, metodologicznych i wreszcie praktycznych na poziomie każdej organizacji gospodarczej, nie należałoby w dobie gospodarki opartej na wiedzy rezygnować $\mathrm{z}$ dalszych dociekań $\mathrm{w}$ tej tak złożonej materii.

\section{BIBLIOGRAFIA}

Bratnicki M., Pomiar kapitatu intelektualnego, „Ekonomika i Organizacja Przedsiębiorstwa” 2000, nr 11.

Bratnicki M., Strużyna J., Dyduch W., Kapitat intelektualny - odwieczne problemy a nowe propozycje metodologiczne, [w:] Kapitat intelektualny, dylematy $i$ wyzwania, WSB-NLU, Nowy Sącz 2001

D obij a D., Możliwości pomiaru kapitału intelektualnego organizacji i jego prezentacji w sprawozdaniach finansowych, Zeszyty Naukowe AE w Krakowie, Z. 553, Kraków 2000.

D u r a j J. (red.), Instrumenty i sposoby zarzq̨dzania kapitałem przedsiębiorstwa, ,Acta Universitatis Lodziensis" 2012, Folia Oeconomica 267, Wydawnictwo Uniwersytetu Łódzkiego, Łódź.

Fijałkowska J., Finansowe $i$ nie finansowe metody pomiaru oraz prezentacji $w$ sprawozdaniach kapitału intelektualnego, rozprawa doktorska, SWSPiZ, Łódź 2009.

Poc z to w s ki A., Zarzqdzania zasobami ludzkimi, PWE, Warszawa 2007. 
Sokołowski J., Strategia wynagrodzeń a budowa kapitału intelektualnego przedsiębiorstwa, [w:] E. Urbanowska-Sojkin (red.), Wybory strategiczne $w$ przedsiębiorstwach, Wydawnictwo Uniwersytetu Ekonomicznego w Poznaniu, Poznań 2011.

S okołowski J., Jóźwi c ki R., Wynagrodzenia naczelnego kierownictwa a efektywność $i$ wartość spótek kapitałowych, [w:] J. D u raj, Przedsiębiorstwo na rynku kapitałowym, Wydawnictwo Uniwersytetu Łódzkiego, Łódź 2010.

Sopińska A., Wachowiak P., Jak mierzyć kapitat intelektualny $w$ przedsiębiorstwie, „E-Mentor” 2004, nr 2.

Urbanek G., Bohdanowicz L., Krytyczna analiza wspótczynnika intelektualnej wartości dodanej, „Przegląd Organizacji” 2012, nr 11.

U rb a n e $\mathrm{P} .$, Nadzór korporacyjny a wynagrodzenia menedżerów, Wydawnictwo Uniwersytetu Łódzkiego, Łódź 2005.

$\mathrm{W}$ i atra k A. P., Zarzqdzanie wiedzq i kapitatem intelektualnym $w$ organizacji - istota i podstawowe zależności, „Problemy Zarządzania” 2007, nr 4.

Jarostaw Sokołowski

\section{INTELLECTUAL CAPITAL AND MANAGERS REMUNERATIONS AND PERFORMANS APPRAISAL}

Top-managers are the people, who have a most important influence on company value end creating and utilizing intellectual capital of company. So very important for business development and its quality factors are payments and performances appraisal systems. In this article we presents the key problems of measurement intellectual capital as the component of company value. Next we presents two roles, which plays managers in creating and utilizing the intellectual capital in companies. We presents so some proposals to managers remunerations systems which should be effective on this field. They are the long term incentives /LTI/, which can create long term motivation of managers to building the intellectual capital and value of companies. For example, success compensations and managers options have be good mechanisms to connecting managers remunerations with intellectual capital in companies.

Key words: company value, intellectual capital, top-managers, managers remunerations, long term incentives. 